\title{
Preeclamptic placental stress and over expression of mitochondrial HSP70
}

\section{Ekambaram Padmini*, Srinivasan Lavanya and Venkatraman Uthra}

P.G. Department of Biochemistry, Bharathi Women's College, Affiliated to University of Madras, Chennai, Tamilnadu, India

\begin{abstract}
Background: Evidence is accumulating that mitochondrial (Mt) oxidative stress plays a role in the pathogenesis of preeclampsia. The current study analyzes the stress levels, energy status and associated enzymatic alteration in placental mitochondria of preeclamptic $(n=30)$ and normotensive $(n=35)$ subjects. Methods: Total Mt stress was measured using dichlorofluorescin (DCFH) oxidant analysis, malondialdehyde (MDA) concentrations, protein carbonyl (PC) concentrations and measurement of nitrite $\left(\mathrm{NO}_{2}^{-}\right)$and nitrate $\left(\mathrm{NO}_{3}^{-}\right)$. Activity of antioxidant enzymes including superoxide dismutase (SOD), glutathione peroxidase (GPX) and the glutathione redox ratio (GRR) were measured. The ATP/ADP (adenosine triphosphate/adenosine diphosphate) concentrations and respiratory chain enzyme activities were also analyzed. The expression of heat shock protein 70 (HSP70) was measured in mitochondria.

Results: The DCFH oxidants, MDA, PC concentrations, and concentrations of $\mathrm{NO}_{2}^{-}$and $\mathrm{NO}_{3}^{-}$were significantly higher in the preeclamptic group $(p<0.01)$ compared with the control group. The activities of SOD, GPx, GRR [glutathione (GSH)/glutathione disulfate (GSSG)] $(p<0.01, p<0.001)$, ATP/ADP and respiratory chain enzyme activities were reduced significantly $(p<0.001)$ in preeclamptic conditions. The placental mitochondrial HSP70 (mtHSP70) showed significant over expression in the preeclamptic group $(p<0.001)$ compared with the control group.

Conclusions: These results provide the first line of evidence for accumulated Mt stress demonstrated by increased stress markers, decreased antioxidants and enhanced mtHSP70. The study illustrates the probable protective mechanism of mtHSP70 against the generated stress. This is primarily to combat the enzymatic and free radical mediated damage produced in preeclampsia.

Clin Chem Lab Med 2009;47:1073-80.
\end{abstract}

Keywords: antioxidants; energy status; heat shock protein 70 (HSP70); oxidative stress; preeclampsia.

*Corresponding author: Dr. E. Padmini, Reader in Biochemistry, Bharathi Women's College, Affiliated to University of Madras, Chennai - 600108, Tamilnadu, India Phone: +91-044-26213748, Fax: +91-044-25280473, E-mail: ntrfbwc@gmail.com; dstpadmini@rediffmail.com Received March 25, 2009; accepted June 16, 2009

\section{Introduction}

Preeclampsia is a serious disorder of pregnancy, characterized by decreased utero-placental perfusion, increased trophoblast cell death and generalized activation of maternal endothelial cells. It is one of the major indications for elective premature delivery (1). Oxidative stress is currently thought to be the mechanism behind the pathogenesis of preeclampsia. Increased lipid peroxides (LPOs) and reduced antioxidant activity may contribute to the development of complications during preeclampsia (2). A growing body of evidence indicates that the pathogenesis of preeclampsia is closely associated with oxidative stress occurring in mitochondria (3). Mitochondria are the "energy factory" of cells and maintenance of this activity by preservation of protein content and function is a key aspect at the cellular level (4). It also acts as a primary locus for the intracellular formation and reactions of reactive oxygen species (ROS) or reactive nitrogen species (RNS). Generation of these free radicals occurs by a large number of physiological and non-physiological processes (5). The ROS mediated membrane damage in response to stress results in production of malondialdehyde (MDA), the end product of lipid peroxidation and protein carbonyl (PC), the by-product of protein oxidation. Nitrite $\left(\mathrm{NO}_{2}^{-}\right)$and nitrate $\left(\mathrm{NO}_{3}^{-}\right)$, the major end products of nitric oxide (NO) metabolism, are capable of inducing nitrosation and nitration of endogenous proteins. Peroxynitrite $\left(\mathrm{ONOO}^{-}\right)$promotes oxidation, nitration, and nitrosation of critical components of mitochondria, altering mitochondrial (Mt) energy production (6).

Heat shock proteins (HSPs) or stress proteins are a conserved group of inducible and constitutive proteins that are thought to protect cells from stresses, such as hypoxia, ischemia and ROS that typically result in protein malfolding (7). The constitutive expression of these proteins indicates that in addition to their protective function, they also have an important role in normal cell function, acting as molecular chaperones and taking part in cellular homeostasis (8). The inducible form of the $70 \mathrm{kDa}$ stress protein of heat shock family (HSP70) plays an important role in defense mechanisms against agents that may induce oxidative injury, thereby preventing stress induced protein aggregation and restoring normal protein folding for the maintenance of cellular homeostasis (9). MtHSP70 is essential for driving preproteins across the membrane into the matrix, and constitutes the motor unit of the Mt protein import machinery (10).

Previously, we have found that preeclamptic patients show severe oxidative stress and nitrative stress characterized by increased lipid oxidation 
products and decreased antioxidant defense status, with increased HSP70 expression in homogenates of placental tissue (11).

The links between $\mathrm{Mt}$ oxidative damage and $\mathrm{Mt}$ enzymatic dysfunction have not been completely understood, and the protective mechanism provided by the damage repair system of mitochondria against oxidative stress remains unclear. Thus, in the present study the impact of oxidative and nitrative stress on Mt respiratory chain enzyme activities and ATP concentrations were investigated. In order to gain further insight into the oxidant/antioxidant balance, the oxidative modification of lipids, proteins, antioxidant concentrations and thiol status were studied, along with mtHSP70.

\section{Materials and methods}

\section{Chemicals}

Sulphanilamide, N-1-naphthyl ethylene diamine dihydrochloride, ATP, ADP, NADH (adenosine triphosphate, adenosine diphosphate, micotinamide adenine diphosphate reduced), cytochrome c, collagenase type 1 and trypsin EDTA were purchased from Sigma-Aldrich (St. Louis, Missouri, USA). Mouse monoclonal HSP70 antibody conjugated with alkaline phosphatase (SPA-810) from Stressgen Bioreagents, Columbia, Canada. Dynabead CD31 and magnetic particle separator were purchased from Invitrogen (Carlsbad, CA, USA). All other chemicals, unless specified, were obtained from Sisco Research Laboratories, Mumbai, India

\section{Subjects}

Patients registered in the department of obstetrics and gynecology of a public sector hospital at Chennai in India were enrolled in the study. The study was carried out for a period of 1 year. The sample consisted of 30 preeclamptic patients and 35 normotensive subjects, $20-32$ years of age. Patients with preeclampsia were defined on the basis of the following clinical and laboratory criteria: systolic blood pressure $\geq 140 \mathrm{~mm} \mathrm{Hg}$ and diastolic blood pressure $\geq 90 \mathrm{~mm} \mathrm{Hg}$ noted on at least two occasions, proteinuria concentrations $>3.0 \mathrm{~g} / \mathrm{L}$ measured on at least two random specimens and xanthine oxidase activity of $\sim 2.6$ units $/ \mathrm{mg}$ protein (12). Healthy volunteers who were normotensive, of similar race, body mass index (BMI) and without maternal and fetal complications during pregnancy were selected as control subjects. Clearance was obtained from Hospital Ethical Committee prior to the commencement of the study and informed consent was obtained from all subjects. There were 29 vaginal deliveries and six cesarean sections in the normotensive group. In the preeclamptic group, there were 18 vaginal deliveries and 12 cesarean sections. Pregnant women with other complications, such as premature rupture of membrane (PROM), intrauterine growth retardation (IUGR), gestational diabetes, chorioamnionitis, clinical infections and those undergoing medication were excluded. The clinical characteristics of the preeclamptic patients were tabulated and compared with the normotensive pregnant subjects and the data are presented in Table 1.

Immediately after delivery, placental tissue samples $(2-3 \mathrm{~g}$ each) were collected from preeclamptic patients $(n=30)$ and normal pregnant women $(n=35)$ in a sterile container and processed for the isolation of placental mitochondria.

\section{Isolation of placental endothelial cells}

Placental endothelial cells were isolated using the method of Herr et al. 2007 (13), with slight modifications. Placenta were excised and thoroughly minced, washed in Hank's balanced salt solution (HBSS) and passed through a $90-\mu \mathrm{m}$ sieve. Collagenase type I (Sigma-Aldrich, USA) at $1.4 \mathrm{~mL} / \mathrm{g}$ of placental tissue was added, and the contents shaken at $37^{\circ} \mathrm{C}$ for 80 min. Following several washes with HBSS and centrifugation at $100 \times g$ for $5 \mathrm{~min}$, the pellets were placed on ice. After resuspending and incubating the cell pellet in $0.5 \mathrm{~mL}$ trypsin-EDTA/g tissue, the suspension was passed through a $250-\mu \mathrm{m}$ sieve. The filtrate was centrifuged at $100 \times g$ for $5 \mathrm{~min}$ and the single cell suspension that was obtained was treated with Dynabead CD31 (Invitrogen), and then washed with phosphate buffered saline (PBS) containing $0.1 \%$ bovine serum albumin (BSA). This mixture was incubated at $4^{\circ} \mathrm{C}$ for 20 min with tilting and rotation. The Dynabead endothelial cell complex was collected with a magnetic particle concentrator. The cells were washed twice with PBS and cultured overnight at 1 million cells per culture flask $\left(125 \mathrm{~mm}^{2}\right)$ in M199 medium containing $20 \%$ fetal calf serum in a $5 \% \mathrm{CO}_{2}$ atmosphere at $37^{\circ} \mathrm{C}$. Non-adherent cells and debris were removed by washing 3 times with PBS the following day. Cell survival was determined by the 3-(4,5-dimethyl-2-yl)-2,5diphenyl tetrazolium bromide (MTT) assay.

\section{MTT assay}

The survivality of placental endothelial cells was determined using the MTT assay (14). The endothelial cells were resus-

Table 1 Clinical characteristics of normotensive pregnant women and preeclamptic patients.

\begin{tabular}{|c|c|c|}
\hline Criteria & $\begin{array}{l}\text { Normotensive } \\
\text { subjects }(n=35)\end{array}$ & $\begin{array}{l}\text { Preeclamptic } \\
\text { subjects }(n=30)\end{array}$ \\
\hline Maternal age, years & $25 \pm 6.2$ & $28 \pm 3.8^{\mathrm{NS}}$ \\
\hline Gestational age, weeks & $37.8 \pm 0.4$ & $32.6 \pm 2.5^{\mathrm{a}}$ \\
\hline Pregnancy weight, kg & $59.3 \pm 7.6$ & $68.1 \pm 8.1^{\mathrm{NS}}$ \\
\hline \multicolumn{3}{|c|}{ Pre-pregnancy blood pressure, $\mathrm{mm} \mathrm{Hg}$} \\
\hline Systolic & $112.9 \pm 5.5$ & $115.7 \pm 5.8^{N S}$ \\
\hline Diastolic & $76.3 \pm 5.4$ & $76.7 \pm 4.3^{\mathrm{NS}}$ \\
\hline \multicolumn{3}{|c|}{ Pregnancy blood pressure at term, $\mathrm{mm} \mathrm{Hg}$} \\
\hline Systolic & $120.6 \pm 6.8$ & $165.8 \pm 7.5^{\mathrm{a}}$ \\
\hline Diastolic & $80.8 \pm 8.2$ & $109.1 \pm 7.9^{\mathrm{a}}$ \\
\hline Proteinuria, g/L & Nil & $3.0 \mathrm{~g} / \mathrm{L}^{\mathrm{b}}$ \\
\hline Xanthine oxidase, $\mathrm{U} / \mathrm{mg}$ protein & $1.6 \pm 0.87$ & $2.8 \pm 0.95^{\mathrm{a}}$ \\
\hline Infant birth weight & $3.24 \pm 0.34$ & $2.32 \pm 0.65^{\mathrm{a}}$ \\
\hline
\end{tabular}

NS, not significant; ${ }^{a} p<0.01$, when compared with normotensive pregnancy; ${ }^{b} p<0.001$, when compared with normotensive pregnancy. 
pended in PBS buffer and serially diluted to a concentration of $200 \mu \mathrm{g}$ of protein per $\mathrm{mL}$ of suspension using the same buffer system. One hundred $\mu L$ of the dilutions were plated out into the wells of a microtiter plate in duplicate. In the control wells, PBS alone was incubated to provide the blank for absorbance readings. Ten $\mu \mathrm{L}$ of MTT reagent was added to each well, including controls. After incubation for $1 \mathrm{~h}$, the visualized purple precipitate (formazan product) was solubilized with $1 \mathrm{~mL}$ acidic isopropanol. The plates were covered and left in the dark for $4 \mathrm{~h}$ at room temperature. Absorbance was measured at $560 \mathrm{~nm}$. The relative survivality was calculated by dividing the optical density of sample by the optical density of control well having the PBS buffer solution with MTT reagent, and multiplying by 100 .

\section{Isolation of mitochondria from placental endothelial cells}

The mitochondria were isolated according to the procedure of Zhang et al. (15). Isolated endothelial cells were resuspended in ice-cold RSB buffer $(10 \mathrm{mmol} / \mathrm{L} \mathrm{NaCl}, 1.5 \mathrm{mmol} / \mathrm{L}$ $\mathrm{MgCl}_{2}$, and $10 \mathrm{mmol} / \mathrm{L}$ Tris-HCL, $\mathrm{pH}$ 7.5) and allowed to swell for 5-10 $\mathrm{min}$ followed by homogenization. Cell lysates were added with $2.5 \times \mathrm{MS}$ buffer $(525 \mathrm{mmol} / \mathrm{L}$ mannitol, 175 $\mathrm{mmol} / \mathrm{L}$ sucrose, $12.5 \mathrm{mmol} / \mathrm{L}$ Tris- $\mathrm{HCl}, \mathrm{pH} 7.5$, and $2.5 \mathrm{mmol} / \mathrm{L}$ ethylenediaminetetraacetic acid, $\mathrm{pH}$ 7.5) to a final concentration of $1 \times \mathrm{MS}$, followed by centrifugation at $1300 \times g$ for $5 \mathrm{~min}$ to remove nuclei, unbroken cells, and large membrane fragments. The supernatant was centrifuged at $17,000 \times g$ for $15 \mathrm{~min}$ followed by two washes with $1 \times$ MS buffer. The resultant pellet containing the Mt fraction was suspended in a $0.25-\mathrm{M}$ sucrose solution $(\mathrm{pH} 7.4)$ and homogenized for $1 \mathrm{~min}$. This was then used for further studies. Protein concentrations were estimated by the method of Bradford with the use of BSA as the standard (16).

\section{Assay of succinate dehydrogenase (marker enzyme for mitochondria)}

Succinate dehydrogenase activity was assayed by the method of Green and Narahara (17). The spectrophotometric cuvette contained the following reagents in a total volume of $4 \mathrm{~mL}$ : $1.0 \mathrm{~mL}$ of phosphate buffer, $0.1 \mathrm{~mL}$ of EDTA, $0.1 \mathrm{~mL}$ of BSA, $0.1 \mathrm{~mL}$ of $\mathrm{KCN}, 0.3 \mathrm{~mL}$ of sodium succinate, $0.2 \mathrm{~mL}$ of potassium ferrocyanide and $2 \mathrm{~mL}$ of distilled water. The contents of the cuvette were brought to a temperature of $25^{\circ} \mathrm{C}$. The reference cuvette contained only water and the enzyme control cell contained all the reagents except substrate. At time zero, $0.2 \mathrm{~mL}$ of suitably diluted enzyme preparation was added to the "test" and "control" cuvette and the extinction at $475 \mathrm{~nm}$ was followed as a function of time for a total period of $5 \mathrm{~min}$ at $30 \mathrm{~s}$ intervals using a Shimadzu UV Spectrophotometer (Tokyo, Japan). The specific activity was expressed as the rate of change in $\mathrm{OD} / \mathrm{min} / \mathrm{mg}$ protein of mitochondria.

\section{Estimation of ROS and RNS by dichlorofluorescin (DCFH) method}

The generation of ROS and other oxidants was evaluated in the mitochondria of both control and test group using DCFH as a probe, according to the method of Kim et al. $(18,19)$. The DCFH assay is sensitive to both ROS and NO, including its derivatives, in the defined assay conditions. For the Mt $\mathrm{DCFH}$ assay, isolated mitochondria were incubated in the assay buffer $(20 \mathrm{mM}$ Tris- $\mathrm{HCl}, 130 \mathrm{mM} \mathrm{KCl}, 5 \mathrm{mM} \mathrm{MgCl}$, $20 \mathrm{mM} \mathrm{NaH} \mathrm{PO}_{4}, 30 \mathrm{mM}$ glucose and $5 \mu \mathrm{M}$ DCFH pH 7.4 malate and pyruvate as site one substrates) at $37^{\circ} \mathrm{C}$ for $15 \mathrm{~min}$. The solution was then centrifuged at $12,000 \times g$ for
$8 \mathrm{~min}$ and the supernatant containing excess DCFH-diacetate was discarded. The Mt pellets were resuspended in the assay buffer, and $50 \mu \mathrm{L}$ of the suspension ( $\approx 2 \mathrm{mg}$ protein) were used for the assay. Dichlorofluorescein (DCF) formation was measured at the excitation wavelength of $488 \mathrm{~nm}$ and an emission wavelength of $525 \mathrm{~nm}$ for $30 \mathrm{~min}$ using a Shimadzu fluorescence spectrometer. All assays were performed in duplicate. The results were expressed in pmol of DCF formed $/ \mathrm{min} / \mathrm{mg}$ protein of placental endothelial mitochondria.

\section{Estimation of LPOs by HPLC}

The concentrations of placental mitochondria MDA, which is the end product of lipid peroxidation, was measured using high performance liquid chromatography (HPLC) according to the method of Lykkesfeldt (20). The samples were prepared as described previously (11). After cooling, the mixture was mixed vigorously with $200 \mu \mathrm{L}$ of $\mathrm{H}_{2} \mathrm{O}$ and $1000 \mu \mathrm{L}$ of butanol-pyridine (15:I by volume). The organic layer was separated by centrifugation ( $3 \mathrm{~min}$ at $16,000 \times g$ ). Calibration curves were constructed using 1,1',3,3'-tetramethoxy propane $(2.5-50 \mu \mathrm{mol} / \mathrm{L})$. Butanolic extracts were analyzed with a Shimadzu 10 VP series model UV-visible spectrophotometer with a detector $\left(\lambda_{\max }-481\right)$ monitored at $532 \mathrm{~nm}$. Chromatographic separation was achieved on Zorbax eclipse $\mathrm{C}_{18}$ column of $5 \mu \mathrm{m}$ particle size; column size $250 \mathrm{~mm} \times 4.6 \mathrm{~mm}$ fitted with a security guard $\mathrm{C}_{8}$ guard column. The mobile phase consisted of $650 \mathrm{~mL}$ of $50 \mathrm{mmol} / \mathrm{L}$ sodium phosphate buffer, pH 6.2, mixed with $350 \mathrm{~mL}$ of methanol. The flow rate of the mobile phase was $1 \mathrm{~mL} / \mathrm{min}$. The sample injection volume was $20 \mu \mathrm{L}$ and the MDA [thio-barbituric acid (TBA)] adduct was eluted at $4.1 \mathrm{~min}$. The results were expressed as $\mathrm{nmol}$ of MDA formed/mg protein.

\section{Determination of protein carbonyls (PCs)}

The method of Levine et al. was used for the determination of PC levels (21). The procedure involves the derivatization of the carbonyl group with 2,4-dinitrophenylhydrazine (DNPH). This results in the formation of a stable 2,4-dinitrophenyl (DNP) hydrazone product that can be measured spectrophotometrically at $370 \mathrm{~nm}$.

\section{Measurement of $\mathrm{NO}_{2}^{-}$and $\mathrm{NO}_{3}^{-}$}

Placental $\mathrm{Mt} \mathrm{NO}_{2}^{-}$and $\mathrm{NO}_{3}^{-}$were estimated by the method of Yokoi et al. with slight modifications using Griess reagent (22). The measurement of $\mathrm{NO}_{2}^{-}$relies on the colorimetric reaction between $\mathrm{NO}_{2}^{-}$, sulfanilamide and $\mathrm{N}$-(1-naphthyl ethylene diamine dihydrochloride) to produce a pink azo product which was measured at $520 \mathrm{~nm}$ using sodium nitrite as standard. For the estimation of $\mathrm{NO}_{3}^{-}$prior to the addition of Griess reagent, all $\mathrm{NO}_{3}^{-}$was converted to $\mathrm{NO}_{2}^{-}$using cadmium sulfate and copper sulfate. The concentrations of $\mathrm{NO}_{3}^{-}$can be obtained by subtracting the value of $\mathrm{NO}_{2}^{-}$from total $\mathrm{NO}_{2}^{-}$(nitrite content + nitrate converted to nitrite). The concentrations of $\mathrm{NO}_{2}^{-}$and $\mathrm{NO}_{3}^{-}$were expressed as $\mu \mathrm{mol} / \mathrm{mg}$ protein.

\section{Respiratory chain enzyme activity assays}

Membrane bound Mt enzyme activities were assayed spectrophotometrically using $100 \mathrm{mM}$ phosphate buffer (pH 7.4) at $30^{\circ} \mathrm{C}$. For the determination of $\mathrm{NADH}$-cytochrome c reductase activity, Mt fragments were incubated with $0.2 \mathrm{mM}$ $\mathrm{NADH}, 0.1 \mathrm{mM}$ cytochrome $\mathrm{c}$ and $1 \mathrm{mM}$ potassium cyanide, and absorbance at $550 \mathrm{~nm}$ was monitored $(\varepsilon=19.6 \mathrm{mM} / \mathrm{cm})$. The enzyme activity was expressed as nmol of cytochrome $c$ reduced $/ \mathrm{min} / \mathrm{mg}$ of protein. Succinate cytochrome c reduc- 
tase activity was determined in a similar manner, except that NADH was substituted with $20 \mathrm{mM}$ succinate.

Cytochrome c oxidase activity was determined by mixing phosphate buffer $\mathrm{pH} 7.4$ with $20 \mu \mathrm{M}$ reduced cytochrome c (prepared by mixing oxidized cytochrome $\mathrm{c}$ and potassium ascorbate) and $20 \mu \mathrm{g} \mathrm{Mt}$ protein (23). After the addition of the $\mathrm{Mt}$ fraction, the reaction was followed at $30^{\circ} \mathrm{C}$ for $2 \mathrm{~min}$ and the absorbance of completely oxidized cytochrome $\mathrm{c}$ measured at $15 \mathrm{~s}$ intervals following the addition of $0.05 \mathrm{~mL}$ of $0.05 \mathrm{M}$ potassium ferricyanide. The enzyme activity was best expressed as the first order velocity constant for the oxidation of cytochrome $C$. The specific activity was expressed as nmol of cytochrome c oxidized/min/mg protein.

\section{Measurement of ATP/ADP}

HPLC analysis of ATP concentrations was determined according to the method of Anderson and Murphy (24). In this procedure, $0.6 \mathrm{~mol} / \mathrm{L}$ perchloric acid was added to an aliquot of Mt sample and immediately cooled on ice for $30 \mathrm{~min}$, and then centrifuged at $6000 \times \mathrm{g}$ at $4^{\circ} \mathrm{C}$ for $10 \mathrm{~min}$. The acid supernatant was removed and quickly neutralized with $1 \mathrm{~mol} / \mathrm{L}$ potassium hydroxide. The suspension was centrifuged to remove insoluble material. The sample $(10 \mu \mathrm{L})$ was injected into the HPLC column symmetry C18 (Waters column $5 \mu \mathrm{m}, 3.9 \times 150 \mathrm{~mm})$; ammonium di-hydrogen phosphate buffer (0.1 M, pH 5.3) was used as the eluent. The ATP and the ADP values were expressed as nmol of ATP or ADP/ $\mathrm{mg}$ of Mt protein.

\section{Assay of SOD and GPx activities}

The activity of SOD was measured according to the procedure of Misra and Fridovich (25). This procedure is based on monitoring the change in absorbance after adding $0.5 \mathrm{~mL}$ of epinephrine to the reaction mixture containing $2.5 \mathrm{~mL}$ of carbonate: bicarbonate buffer and $0.5 \mathrm{~mL}$ of EDTA at $420 \mathrm{~nm}$ for $2 \mathrm{~min}$, at $15 \mathrm{~s}$ time intervals. Auto oxidation of epinephrine was also monitored in the reaction mixture without adding the enzyme source. The activity of the enzyme was expressed as units of $\mathrm{SOD} / \mathrm{min} / \mathrm{mg}$ protein. The glutathione peroxidase (GPx) activity was determined according to the method of Rotruck et al. (26). This procedure involves the analysis of GSH at $412 \mathrm{~nm}$ using 5,5' dithiobis-(2-nitrobenzoic acid) (DTNB). The activity of GPx is expressed as $\mu \mathrm{g}$ of GSH consumed/min/mg protein (14).

\section{Determination of GSH/GSSG (GRR)}

Thiol status was assessed spectrofluorimetrically using the method of Hissin and Hilf (27). This method is based on the reaction of O-phthaldehyde (OPT) as a fluorescent reagent with $\mathrm{GSH}$ at $\mathrm{pH} 8.0$ and GSSG at pH 12.0. In the measurement of GSSG, GSH was complexed to $\mathrm{N}$-ethylmaleimide (NEM) to prevent its interference. The fluorescence and excitation were determined at $420 \mathrm{~nm}$ and $350 \mathrm{~nm}$, respectively. The values were expressed as $\mathrm{nmol} / \mathrm{mg}$ protein.

\section{Western blotting of HSP70}

Western blotting was performed according to the method of Towbin et al. (28). The placental Mt samples (100 $\mu \mathrm{g}$ of protein) were analyzed by electrophoresis on $10 \%$ sodium dodecyl sulfate polyacrylamide gel. The separated proteins were electrotransferred from the gel slabs onto 0.45 $\mu \mathrm{M}$ polyvinylidene fluoride (PVDF) membrane (Biotrace, Dreieich, Germany). The membrane was then blocked with
$5 \%$ non-fat skimmed milk powder prepared in $0.1 \mathrm{M}$ PBSTween 20 buffer (Blotto) overnight with agitation. This was followed by probing with mouse alkaline phosphatase conjugated monoclonal antibody raised against HSP70 (SPA810, Stressgen, Canada) diluted in the ratio of 1:2000 with PBS buffer. The blot was removed from the antibody and washed with PBS buffer in triplicate. The 5-bromo-4-chloro3-indolyl phosphate and nitroblue tetrazolium (BCIP-NBT) substrate (Sigma, St. Louis, MO, USA) system was used to detect the alkaline phosphatase conjugate as described by the manufacturer. The band intensities were scanned with the HP scanners (HP PSC 1310 series) and quantified using the Total Lab image analysis software (Nonlinear dynamics, All Saints, UK).

\section{Statistical analysis}

The results were expressed as mean value \pm SD. Statistical analysis of the data was carried out using Statistical Package for Social Sciences (SPSS) 7.5 version package (Chicago, IL, USA). Statistical significance was determined by comparing the results of preeclamptic patients with the normotensive group using Student's t-test. Differences were determined to be statistically significant for values of $p<0.01$ and $\mathrm{p}<0.001$

\section{Results}

\section{Cell viability of endothelial cells}

The cell viability of endothelial cells isolated from the normotensive pregnant women and preeclamptic patients is shown in Figure 1. The endothelial cells isolated from preeclamptic women had a significant decrease in viability $(p<0.01)$.

\section{Oxidant production in placental endothelial mitochondria}

Oxidant production as revealed by DCFH oxidation rate in the placental mitochondria was increased in preeclampsia (Figure 2). Preeclamptic patients had a $32 \%$ higher DCFH oxidation rate than normotensive pregnant women, this difference was significant $(p<0.01)$.

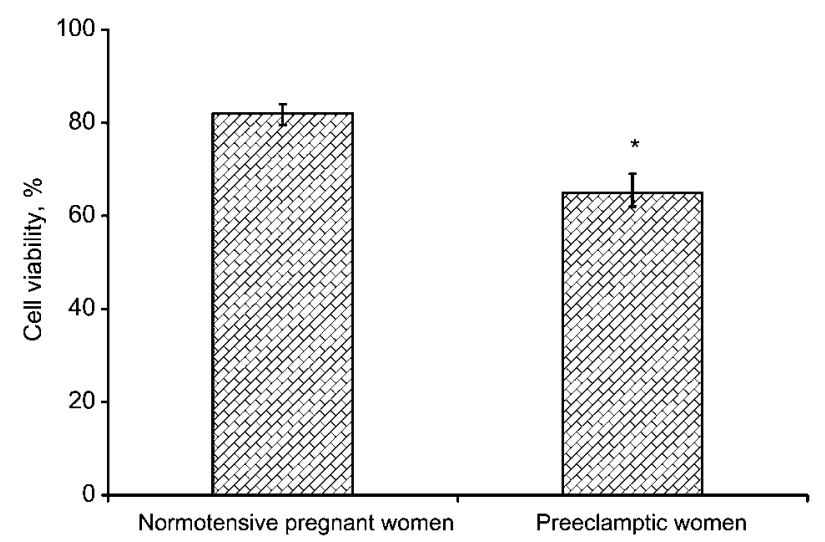

Figure 1 Cell survivality of endothelial cells isolated from normotensive and preeclamptic placenta.

Each bar represents mean $\pm S D$. ${ }^{*} p<0.01$ normotensive vs. preeclamptic pregnancies. 


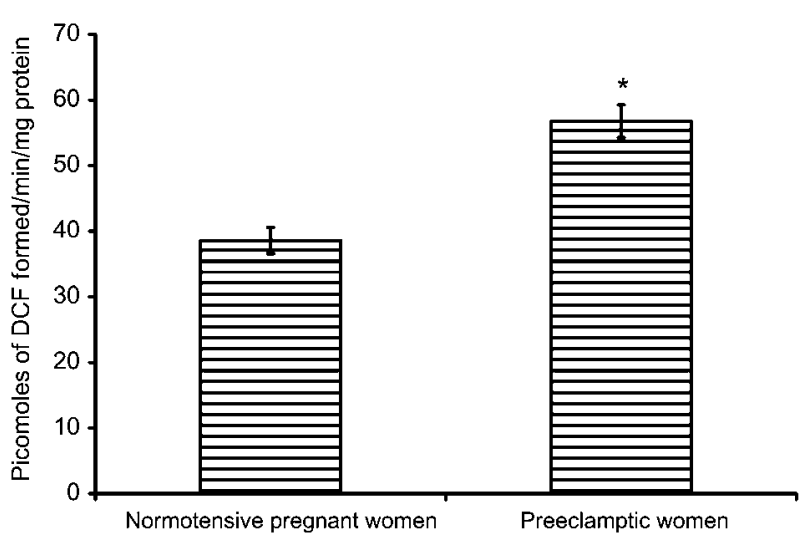

Figure 2 Oxidation rate of dichlorofluorescin (DCFH) to dihydrofluorescein (DCF) in placental mitochondria of normotensive pregnant women and preeclamptic patients.

Each bar represents mean $\pm S D$. ${ }^{*} p<0.01$ normotensive vs. preeclamptic pregnancies.

\section{Lipid peroxidation, protein oxidation and nitrative stress in placental endothelial mitochondria}

The concentrations of LPO product MDA, protein oxidation product $\mathrm{PCs}$, the $\mathrm{NO}$ metabolites $\mathrm{NO}_{2}^{-}$and $\mathrm{NO}_{3}^{-}$in the placental endothelial mitochondria of the preeclamptic patients and normal healthy volunteers are presented in Table 2. The concentration of MDA was significantly higher in the preeclamptic group $(p<0.01)$ compared with the control group. The concentrations of $\mathrm{NO}_{2}^{-}$and $\mathrm{NO}_{3}^{-}$, which were significantly increased $(p<0.001)$ in the preeclamptic group compared with the control group, were the primary oxidation products of $\mathrm{NO}$ following the reaction with oxygen. The $\mathrm{NO}_{2}^{-} / \mathrm{NO}_{3}^{-}$concentration is usually used as an indicator of NO synthesis. PCs, the product of oxidative modification of proteins, were increased significantly $(p<0.01)$ in the preeclamptic group compared to the normotensive group.

\section{Antioxidant enzyme activities}

The activities of antioxidant enzymes, such as SOD, GPx concentrations and the GSH/GSSG ratio were determined in the enriched Mt fraction. The activities of SOD, a specific Mt antioxidant enzyme $(p<0.001)$, and GPx $(p<0.01)$ were significantly decreased in preeclamptic placental Mt samples compared with control samples (Table 3). The glutathione redox ratio (GRR) GSH/GSSG (Figure 3) was significantly decreased $(p<0.001)$. This was because the GSSG concentration was increased and the GSH concentration reduced in placental mitochondria of the preeclamptic group compared with the normotensive control group.

\section{Respiratory complex activities}

The activities of Mt respiratory chain enzymes, complex I (NADH-cytochrome c reductase) and complex II (succinate-cytochrome $\mathrm{c}$ reductase) were significantly reduced by $30 \%(p<0.01)$ in preeclamptic patients compared with control samples (Table 4). The complex IV activity, expressed as nmol of cytochrome c oxidized $/ \mathrm{min} / \mathrm{mg}$ protein, also showed a significant decrease $(50 \%$ lower), where the value fell from $138 \pm 7.59$ in the control group to $84 \pm 8.14$ in the preeclamptic group.

\section{Energy status}

The concentrations of ATP and ADP measured in normotensive and preeclamptic placental mitochondria are illustrated in Figure 4. The finding of decreased ATP and increased ADP leading to an altered ATP/ ADP ratio was observed to be significant $(p<0.001)$ between the two groups.

\section{HSP70 expression}

The alteration in the cytoprotective mtHSP70 expression in preeclamptic patients in response to stress, analyzed in the placental mitochondria of both groups, is shown in Figure 5. The results revealed that MtHSP70 concentrations were significantly increased $(p<0.001)$ in preeclamptic patients compared with controls indicating the adaptive nature of their $\mathrm{Mt}$ cells during conditions of stress.

\section{Discussion}

The preeclamptic syndrome is more often associated with placental abnormalities, such as improper trophoblast invasion, vasoconstriction and poor villous development (1). Endothelial cell dysfunction is the major pathophysiologic finding in preeclampsia. Endothelial cells acting as an interface for maternofetal interaction play a pivotal role in trophoblast migration, placental implantation and organ formation in the developing embryo. Emerging evidence shows that the increased oxidative and nitrative

Table 2 Concentrations of LPO, nitric oxide metabolites $\mathrm{NO}_{2}^{-}$and $\mathrm{NO}_{3}^{-}$and $\mathrm{PCs}$ in the placental tissue mitochondria of preeclamptic patients and normotensive pregnant women.

\begin{tabular}{lll}
\hline Parameters & $\begin{array}{l}\text { Normotensive pregnant } \\
\text { women }(\mathrm{n}=35)\end{array}$ & $\begin{array}{l}\text { Preeclamptic } \\
\text { women }\end{array}$ \\
\hline $\mathrm{MDA}=30)$
\end{tabular}

MDA, malondialdehyde; $\mathrm{NO}_{2}^{-}$, nitrite; $\mathrm{NO}_{3}^{-}$, nitrate; $\mathrm{PC}$, protein carbonyl; $\mathrm{LPO}$, lipid peroxides. ${ }^{\mathrm{a}} \mathrm{p}<0.01$, when compared with normotensive pregnancy; ${ }^{\mathrm{b}} \mathrm{p}<0.001$, when compared with normotensive pregnancy. 
Table 3 Activities of antioxidant enzymes SOD and GPx in the placental tissue of preeclamptic patients and of normal healthy volunteers.

\begin{tabular}{lll}
\hline Parameters & Normotensive pregnant & $\begin{array}{l}\text { Preeclamptic } \\
\text { women }(\mathrm{n}=30)\end{array}$ \\
\hline SOD, U/min/mg/protein & $3.62 \pm 0.22$ & $1.8 \pm 0.15^{\mathrm{b}}$ \\
GPx, $\mathrm{nmol}$ of glutathione consumed $/ \mathrm{min} / \mathrm{mg}$ protein & $0.29 \pm 0.047$ & $0.21 \pm 0.035^{\mathrm{a}}$ \\
\hline
\end{tabular}

$\mathrm{SOD}$, superoxide dismutase; GPx, glutathione peroxidase. ${ }^{\mathrm{a}} \mathrm{p}<0.01$, when compared with normotensive pregnancy; ${ }^{\mathrm{b}} \mathrm{p}<0.001$, when compared with normotensive pregnancy.

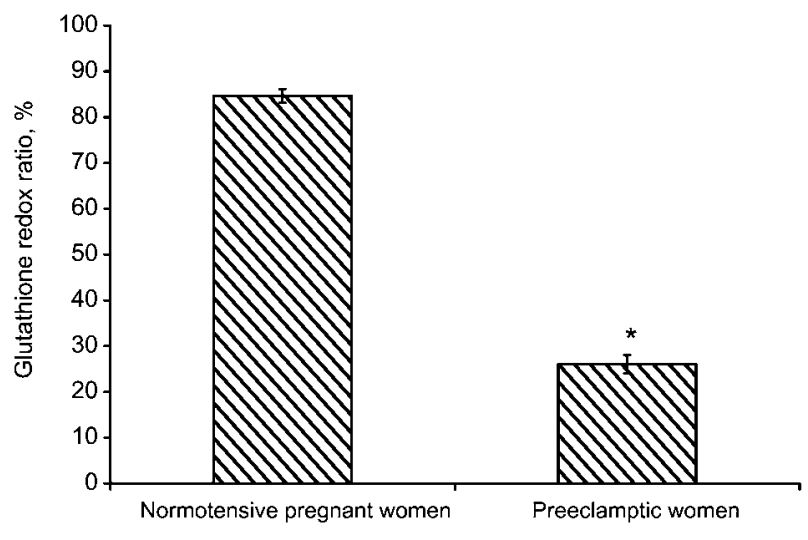

Figure $3 \mathrm{GSH} / \mathrm{GSSG}$ in the placental tissue mitochondria of normotensive pregnant women and preeclamptic patients. Values are expressed as mean $\pm S D$. ${ }^{*} p<0.001$ normotensive vs. preeclamptic pregnancies.

stress resulting in cell damage begins in the mitochondria, which are the major sites of production of free radical species (ROS, RNS) $(6,29)$. The survivability of endothelial cells obtained from the MTT assay confirmed a decrease in viability under conditions of preeclampsia. Mt viability, assessed with the marker enzyme succinate dehydrogenase, provided similar results. The decrease in Mt viability during preeclampsia as a result of $\mathrm{Mt}$ damage through oxidative stress remains inevitable (30).

The enhanced preeclamptic $\mathrm{Mt}$ stress assessed through $\mathrm{LPO}, \mathrm{PC}, \mathrm{NO}_{2}^{-}, \mathrm{NO}_{3}^{-}$, DCFH clearly demonstrates that mitochondria acts as the primary loci for free radical damage. In the present investigation, the rate of DCFH oxidation was increased by $32 \%$ in preeclamptic conditions, indicating the overproduction of free radicals (ROS and RNS) compared with normotensive subjects. The increase in $\mathrm{NO}_{3}^{-} / \mathrm{NO}_{2}^{-}$during preeclampsia is a result of increased production of NO, a vasodilator (31). NO is highly unstable and gets converted to $\mathrm{NO}_{3}^{-} / \mathrm{NO}_{2}^{-}$(32). Antioxidant defenses in preeclampsia are comparatively weak, either due to the uncontrolled increase in oxidative stress or due to their improper functioning under conditions of abnormal stress (33). This is evident from the decreased activities of SOD and GPx noted in preeclamptic mitochondria. NO can oxidize intracellular reduced GSH and thus, alter the thiol status by changing GSH and GSSG concentrations (19). Consistent with this, a reduction in GRR was observed in mitochondria during preeclampsia. GSH has been known to provide the cell with a reducing environment in addition to maintaining protein in a reduced state. The GSH redox status might entail a dynamic regulation of protein function (34). The Mt pool of GSH is considered vital for cell survival and significant depletion also leads to stress situation (35). The activity of GPx which requires GSH for its function is affected with the concomitant accumulation of hydrogen peroxide and hydroxyl radicals, further enhancing the state of oxidative or $\mathrm{NO}_{3}^{-}$stress. These results indicate that overproduction of free radical species consumes endogenous antioxidants and overwhelms the antioxidant capacity.

$\mathrm{ONOO}^{-}$, a harmful oxidant formed by the reaction between superoxide and NO, acts as a major source of NO-dependent dysfunction in mitochondria through its oxidizing and nitrating properties. It also inhibits respiratory complexes I, II, and IV $(36,37)$. In line with this finding, a reduction in the activities of complex I (NADH-cytochrome c reductase), complex II (succinate-cytochrome c reductase) and complex IV (cytochrome c oxidase) of the respiratory chain that we observed indicates selective $\mathrm{ONOO}^{-}$mediated $\mathrm{Mt}$ damage. The decrease in NADH-cytochrome c reductase activity accompanied by minimal alteration in succinate-cytochrome $\mathrm{c}$ reductase activity observed in our study indicates selective damage to NADH-dehydrogenase produced by $\mathrm{Mt} \mathrm{ONOO}^{-}$(38).

Table 4 Mitochondrial respiratory enzyme activities in the placental tissue mitochondria of preeclamptic patients and normal healthy volunteers.

\begin{tabular}{lll}
\hline Parameters & $\begin{array}{l}\text { Normotensive pregnant } \\
\text { women }(\mathrm{n}=35)\end{array}$ & $\begin{array}{l}\text { Preeclamptic } \\
\text { women }(\mathrm{n}=30)\end{array}$ \\
\hline $\begin{array}{l}\mathrm{NADH}-\text {-cytochrome c reductase } \\
\mathrm{NADH} \rightarrow \mathrm{Cyt} \mathrm{c}^{3+}\end{array}$ & $445 \pm 16.45$ & $387 \pm 14.23^{\mathrm{a}}$ \\
$\begin{array}{l}\text { Succinate-cytochrome c reductase } \\
\quad \text { Succinate } \rightarrow \text { Cyt c }\end{array}$ & $126 \pm 8.76$ & $103 \pm 11.92^{\mathrm{a}}$ \\
$\begin{array}{l}\text { Cytochrome c oxidase } \\
\text { Cyt c }\end{array} \mathrm{O}_{2}$ & $138 \pm 7.59$ & $84 \pm 8.14^{\mathrm{b}}$ \\
\hline
\end{tabular}

Specific activity of the enzyme expressed as nmol of cytochrome c oxidized/min/mg protein. ${ }^{a} p<0.01$, when compared with normotensive pregnancy; ${ }^{b} p<0.001$, when compared with normotensive pregnancy. 


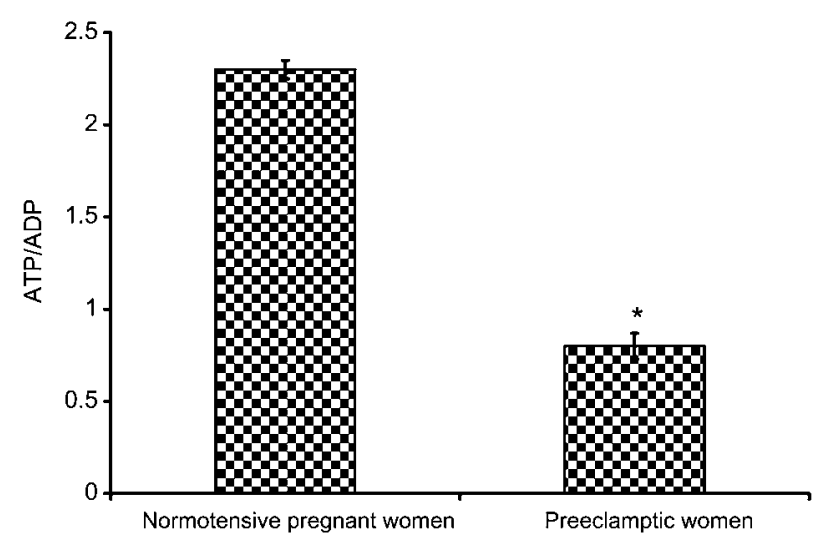

Figure 4 ATP/ADP in the placental tissue mitochondria of normotensive pregnant women and preeclamptic patients. Values are expressed as mean $\pm S D$. ${ }^{*} p<0.001$ normotensive vs. preeclamptic pregnancies.

The placenta is responsible for supplying oxygen and substrates to the fetus. The function of placental cells is dependent on energy supplied by the mitochondria. Changes in the function and activities of placental Mt respiratory chain enzymes of preeclamptic patients noted in the present study are in accordance with an increased $\mathrm{Mt}$ dysfunction since respiratory complexes are critical for the maintenance of cellular energy $(39,40)$. Under conditions of highenergy demand, such as during oxidative stress, the placenta may experience energy shortages due to inability of the mitochondria to produce ATP. Therefore, the decrease in intracellular ATP concentrations would result in disturbances in $\mathrm{Mt}$ bioenergetics. The increased PC formed due to oxidative damage of the inner Mt membrane leads to decreased ability of the mitochondria to retain calcium which is an uncoupler of oxidative phosphorylation. This leads to impairment of ATP synthesis, which in turn affects Mt membrane integrity and a decreased ATP/ADP ratio (41). Similarly a reduced ATP/ADP ratio was noted in preeclamptic mitochondria. Severe depletion of ATP is a proteotoxic stress that leads to dysfunction, destabilization and aggregation of many cellular proteins (42). The stress may serve as a signal to initiate

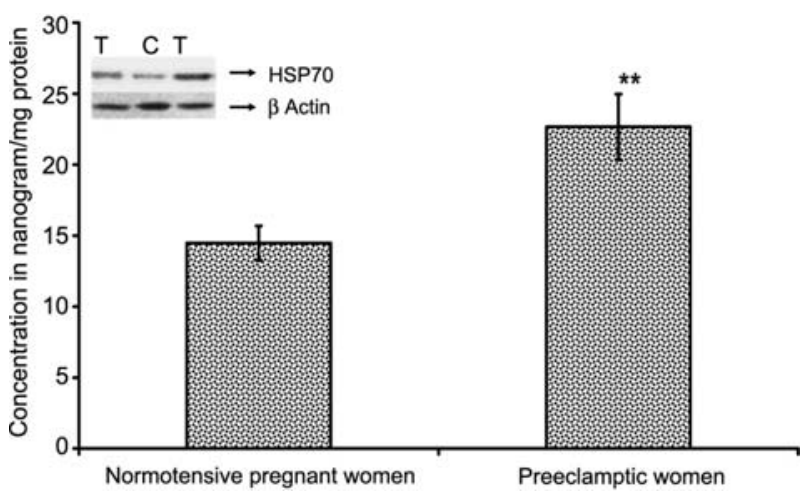

Figure 5 Western blot and quantification of HSP70 in the placental tissue mitochondria of normotensive pregnant women and preeclamptic patients.

$\mathrm{T}$, preeclamptic group; C, normotensive pregnant group. ** $p<0.001$ compared to normotensive pregnant women. and propagate inflammatory processes resulting in apoptosis of placental tissue. It is also well established that the activation of apoptosis is associated with ROS produced by mitochondria (43). The HSPS may be involved in adaptive response during such conditions.

The present investigation demonstrates the inhibition of Mt respiratory complexes, especially cytochrome $c$ oxidase $(p<0.001)$, metabolic stress (decrease in ATP), increase in oxidative stress and nitrative stress. Alteration in antioxidant concentrations may result in up-regulation of $\mathrm{Mt}$ stress protein HSP70. The Mt stress causes more inflow of HSP70 from the cytoplasm into mitochondria. This may help to maintain the function of the respiratory complexes and suppress Mt ROS production through stabilization of cytochrome c (44). The over expression of HSP70 also mediates the folding and assembly of Mt proteins, serving as an additional mechanism leading to the preservation of respiratory complex activities. The increase in the concentrations of mtHSP70 is also associated with the prevention of NO-dependent increase in cellular free iron from the Mt respiratory complexes, thereby maintaining their integrity (45). In brief, this study reveals the involvement of Mt stress during preeclampsia and the possible protective role of Mt HSP70 combating the generated stress.

\section{Acknowledgements}

The present work is funded by National Tea Research Foundation, Tea Board of India. Project referral number: NTRF: 115/07.

\section{References}

1. Soleymanlou N, Wu Y, Wang JX, Todros T, letta F, Jurisicova $A$, et al. A novel Mtd splice isoform is responsible for trophoblast cell death in pre-eclampsia. Cell Death Differ 2005;12:441-52.

2. Poston L, Chappell LC. Is oxidative stress involved in the aetiology of pre-eclampsia? Acta Paediatr Suppl 2001;90: 3-5.

3. Shibata E, Nanri H, Ejima K, Araki M, Fukuda J, Yoshimura $\mathrm{K}$, et al. Enhancement of mitochondrial oxidative stress and up-regulation of antioxidant protein peroxiredoxin III/ SP-22 in the mitochondria of human pre-eclamptic placentae. Placenta 2003;24:698-705.

4. von Janowsky B, Major T, Knapp K, Voos W. The disaggregation activity of the mitochondrial ClpB homolog Hsp78 maintains Hsp70 function during heat stress. J Mol Biol 2006;357:793-807.

5. Radi R, Cassina A, Hodara R. Nitric oxide and peroxynitrite interactions with mitochondria. Biol Chem 2002;383: 401-9.

6. Van $\operatorname{der}$ Vliet A, Eiserich JP, Halliwell B, Cross CE. Formation of reactive nitrogen species during peroxidasecatalyzed oxidation of nitrite: a potential additional mechanism of nitric oxide-dependent toxicity. J Biol Chem 1997;272:7617-25.

7. Mestril R, Dillmann WH. Heat shock proteins and protection against myocardial ischemia. J Mol Cell Cardiol 1995;27:45-52 
8. Hartl FU. Molecular chaperones in cellular protein folding. Nature 1996;381:571-9.

9. Mosser DD, Caron AW, Bourget L, Meriin AB, Sherman MY, Morimoto Rl, et al. The chaperone function of HSP70 is required for protection against stress-induced apoptosis. Mol Cell Biol 2000;20:7146-59.

10. Kang P-J, Ostermann J, Shilling J, Neupert W, Craig EA, Pfanner N. Requirement for hsp70 in the mitochondrial matrix for translocation and folding for precursor proteins. Nature 1990;348:137-43

11. Padmini E, Geetha BV. Placental heat shock protein 70 overexpression confers resistance against oxidative stress in preeclampsia. Turk J Med Sci 2008;38:27-34.

12. Brown MA, Lindheimer MD, de Swiet M, Van Assche A, Moutquin J-M. The classification and diagnosis of the hypertensive disorders of pregnancy: statement from the International Society for the Study of Hypertension in Pregnancy (ISSHP). Hypertens Pregnancy 2001;20: 9-14.

13. Herr $F$, Baal N, Reisinger $K$, Lorenz A, McKinnon $T$, Preissner KT, et al. HCG in the regulation of placental angiogenesis: results of an in vitro study. Placenta 2007:28:S85-93.

14. Mosmann T. Rapid colorimetric assay for cellular growth and survival: application to proliferation and cytotoxicity assays. J Immunol Methods 1983;65:55-63.

15. Zhang H, Luo Y, Zhang W, He Y, Dai S, Zhang R, et al. Endothelial-specific expression of mitochondrial thioredoxin improves endothelial cell function and reduces atherosclerotic lesions. Am J Pathol 2007;170:1108-20: doi: 10.2353/ajpath.2007.060960.

16. Bradford MM. A rapid and sensitive method for the quantitation of microgram quantities of protein utilizing the principle of protein-dye binding. Anal Biochem 1976;72:248-54.

17. Green JD, Narahara HT. Assay of succinate dehydrogenase activity by the tetrazolium method: evaluation of an improved technique in skeletal muscle fractions. J Histochem Cytochem 1980;28:408-12.

18. Lebel CP, Bondy SC. Sensitive and rapid quantitation of oxygen reactive species formation in rat synaptosomes. Neurochem Int 1990;17:435-40.

19. Kim Y-M, Bombeck CA, Billiar TR. Nitric oxide as a bifunctional regulator of apoptosis. Circ Res 1999;84: 253-56.

20. Lykkesfeldt J. Determination of malondialdehyde as dithiobarbituric acid adduct in biological samples by HPLC with fluorescence detection: comparison with ultraviolet-visible spectrophotometry. Clin Chem 2001; 47:1725-27.

21. Levine RL, Garland D, Oliver CN, Amici A, Climent I, Lenz $A G$, et al. Determination of carbonyl content in oxidatively modified proteins. Methods Enzymol 1990;186: 464-78.

22. Yokoi I, Habu H, Kabuto $H$, Mori A. Analysis of nitrite, nitrate, nitric oxide synthase activity in brain tissue by automated flow injection technique. Methods Enzymol 1996;268:152-59.

23. Navarro A, Del Pino MJ, Gómez C, Peralta JL, Boveris A. Behavioral dysfunction, brain oxidative stress, and impaired mitochondrial electron transfer in aging mice. Am J Physiol Regul Integr Comp Physiol 2002;282:R98592.

24. Anderson FS, Murphy RC. Isocratic separation of some purine nucleotide, nucleoside, and base metabolites from biological extracts by high-performance liquid chromatography. J Chromatogr 1976;121:251-62.

25. Misra HP, Fridovich I. The role of superoxide anion in the autoxidation of epinephrine and a simple assay for superoxide dismutase. J Biochem 1972;247:3170-75.
26. Rotruck JT, Pope AL, Ganther HE, Swanson AB, Hafeman DG, Hoekstra WG. Selenium: biochemical role as a component of glutathione peroxidase. Science 1973;179: 588-90.

27. Hissin PJ, Hilf R. A fluorometric method for determination of oxidized and reduced glutathione in tissues. Anal Biochem 1976;74:214-26.

28. Towbin H, Staehelin T, Gordon J. Electrophoretic transfer of proteins from polyacrylamide gels to nitrocellulose sheets: procedure and some applications. Proc Natl Acad Sci USA 1979;76:4350-4.

29. Wang Y, Walsh SW. Placental mitochondria as a source of oxidative stress in pre-eclampsia. Placenta 1998;19: 581-6.

30. Duchen MR. Roles of mitochondria in health and disease. Diabetes 2004;53:S96-102.

31. Pathak N, Sawhney H, Vasishta K, Majumdar S. Estimation of oxidative products of nitric oxide (nitrates, nitrites) in preeclampsia. Aust NZ J Obstet Gynaecol 1999;39:484-7.

32. Buhimschi IA, Saade GR, Chwalisz K, Garfield RE. The nitric oxide pathway in pre-eclampsia: pathophysiological implications. Hum Reprod Update 1998;4:25-42.

33. Chamy VM, Lepe J, Catalán A, Dretamal D, Escobar JA, Madrid EM. Oxidative stress is closely related to clinical severity of pre-eclampsia. Biol Res 2006;39:229-36.

34. Biswas S, Chida AS, Rahman I. Redox modifications of protein-thiols: emerging roles in cell signaling. Biochem Pharmacol 2006;71:551-64.

35. Han D, Canali R, Rettori D, Kaplowitz N. Effect of glutathione depletion on sites and topology of superoxide and hydrogen peroxide production in mitochondria. Mol Pharmacol 2003;64:1136-44.

36. Robinson VK, Sato E, Nelson DK, Camhi SL, Robbins RA, Hoyt JC. Peroxynitrite inhibits inducible (Type 2) nitric oxide synthase in murine lung epithelial cells in vitro. Free Radic Biol Med 2001;30:986-91.

37. Radi R, Cassina A, Hodara R, Quijano C, Castro L. Peroxynitrite reactions and formation in mitochondria. Free Radic Biol Med 2002;33:1451-64.

38. Ramachandran A, Levonen AL, Brookes PS, Ceaser E, Shiva S, Barone MC, et al. Mitochondria, nitric oxide and cardiovascular dysfunction. Free Radic Biol Med 2002;33: 1465-74.

39. Furui T, Kurauchi O, Tanaka M, Mizutani S, Ozawa T, Tomoda Y. Decrease in cytochrome C oxidase and cytochrome oxidase subunit I mRNA levels in preeclamptic pregnancies. Obstet Gynecol 1994;84:283-8.

40. Matsubara S, Minakami H, Sato I, Saito T. Decrease in cytochrome c oxidase activity detected cytochemically in the placental trophoblast of patients with pre-eclampsia. Placenta 1997;18:255-9.

41. Richter C, Kass GE. Oxidative stress in mitochondria: its relationship to cellular $\mathrm{Ca} 2+$ homeostasis, cell death, proliferation, and differentiation. Chem Biol Interact 1991;77:1-23.

42. Kabakov $A E$, Budagova $K R$, Latchman $D$, Kampinga $H H$. Stressful preconditioning and HSP70 over expression attenuate proteotoxicity of cellular ATP depletion Am J Physiol Cell Physiol 2002;283:521-34.

43. Hensley K, Robinson KA, Gabbita SP, Salsman S, Floyd RA. Reactive oxygen species, cell signaling, and cell injury. Free Radic Biol Med 2000;28:1456-62.

44. Voloboueva LA, Duan M, Ouyang Y, Emery JF, Stoy C, Giffard RG. Overexpression of mitochondrial Hsp70/ Hsp75 protects astrocytes against ischemic injury in vitro. J Cerebr Blood Flow Metab 2008;28:1009-16.

45. Wang D, McMillan JB, Bick R, Buja LM. Response of the neonatal rat cardiomyocyte in culture to energy depletion: effects of cytokines, nitric oxide, and heat shock proteins. Lab Invest 1996;75:809-18. 